\title{
Correspondence
}

\section{Patient Rights}

\section{Dear Editors:}

I would like to comment upon the article, Patient Rights: An Agenda for the ' 80 s, by George Annas, published in the April 1981 issue of NURSING LAW \& ETHICS.

As Hospital Attorney for an academic health care center, I understand Professor Annas's strong feelings about patient rights and the need to increase patient rights to avoid dehumanization and paternalism. However, I have some concern about increasing patient rights significantly in these days of dramatically increased malpractice lawsuits.

For example, Professor Annas mentions, in "No Routine Procedures," that routine use of wheelchairs for inhospital transportation should be ruled

\section{Patient Rights Agenda}

1. No Routine Procedures

2. Open Access to Medical Records

3. Twenty-Four-Hour-a-Day Visitor Rights

4. Full Experience Disclosure

5. Effective Patient Advocates

out. In some cases, wheelchairs are unnecessary for physiological reasons but are used in an attempt to minimize slip-and-fall lawsuits. Certainly, I am familiar with hospitals that use wheelchairs for that purpose. Additionally, making a procedure routine ensures that steps will not be forgotten. Especially in the hectic environment of the hospital, it may be useful to have routines that result in an increase in patient health.

Similarly, Professor Annas indicates in "Twenty-Four Hour a Day Visitor Rights" that people should be permitted to stay with the patient during any procedure, for example, childbirth. At least one court has held that there is an increased risk of tort liability if the husband is present during childbirth. If the baby were injured during delivery, the husband could bring a lawsuit for emotional damages. I am not arguing that the suit might not be justified, rather, that hospitals may seek to minimize liability by not allowing a pa- tient's family to accompany her into the delivery room.

Since patients are not allowed to contract away their right to sue, hospitals may want to take steps to minimize liability at the expense of treating patients as individuals. Stating the question certainly does not resolve it, but it does need to be debated in evaluating a patient rights agenda. Indeed, increasing patient rights may result in increased costs since the greater risk of malpractice would be seen as a cost of doing business.

The item, "Full Experience Disclosure," may conflict with the need to train students. In a teaching hospital, students have to grapple with how to tell the patient about their level of experience. Should medical students introduce themselves as studentphysicians, physicians in training, first year house officers, or simply as physicians? Before performing a bone marrow aspiration, should students reveal how many times they have practiced the procedure, how good they think they are at it, how good their supervisor thinks they are, or who they personally think would be the best person in the institution to perform the aspiration? Should the student indicate that the experience of the physician may affect the outcome of some operations, but that for other operations, it makes no difference? I agree that students should have better training about how they present themselves, but I am not sure that a patient who knowingly enters a teaching hospital should be free to refuse care by students.

My last point concerns patient responsibilities. I wonder if Professor Annas has reviewed the Michigan statute on patient rights, which also has a section on patient responsibilities. The first of six paragraphs states: "A patient or resident is responsible for following the health facility rules and regulations affecting patient or resident care and conduct." I I am intrigued by the notion of saying to patients that they have a right to be treated as individuals, but that they also have a responsibility to act appropriately. I wonder about a growing trend in the United States where people argue that they have no responsibility for themselves. A simple-minded example is automobile safety: consumers argue that the gov. ernment should ensure their safety and that they have no individual responsibility to learn about the functioning of automobiles.

This trend towards passivity strikes me as inconsistent with our goal of becoming truly informed consumers. I wonder whether the same trend is starting to occur in health care.

Edward B. Goldman, Esq.

University Hospital

University of Michigan

Ann Arbor, Michigan

\section{References}

I. M.C.L.A. $\$ 333.20202$.

\section{Professor Annas Responds:}

Mr. Goldman's primary response to my "Patient Rights Agenda for the ' 80 s" is to worry that it may increase malpractice litigation. While I appreciate his thoughtful remarks, I believe that this concern (which he shares with others) is misplaced and overstated. There is simply no evidence that affording patients their rights increases lawsuits; instead, better communication with and participation by patients in their care is likely to decrease their propensity to sue. ${ }^{1}$

The examples Mr. Goldman gives illustrate the difficulty of resolving the liability issue abstractly, without hard data. In the wheelchair case, I would guess it is not "some cases" where a wheelchair is unnecessary (President Reagan's being the most recent celebrated case), but the vast majority of cases. Few patients have wheelchairs waiting at the other end of their trip from the hospital, and it is not the journey home that makes it safe for patients to move on their own. Indeed, if the hospital knows that they require wheelchair assistance for safety at the other end of their transfer trip, liability for injury will not be avoided simply by utilizing a wheelchair in the hospital. The way to avoid liability is to ensure that staff understand why wheelchairs are sometimes critical,

Continued on page 36 
Correspondence

Continued from page 28

rather than to impose a routine procedure in cases where it is neither indicated nor wanted.

As to fathers in the delivery room, no liability at all would be imposed in the absence of negligence. Obstetrical lawsuits are best avoided by decreasing negligence in the delivery room, not by excluding fathers from it.

Finally, there is no excuse for students to introduce themselves as anything but students. Teaching them to identify themselves as physicians teaches them that it is acceptable to lie to patients to further their education. It is this philosophy, and the deception it spawns, that leads to far more lawsuits than honesty. Patients have the right to refuse treatment from anyone, including students; those students who gain consent by misrepresenting themselves open themselves up to a battery suit and the facility that encourages this conduct to a negligence action.

Patient rights exist to promote active participation in a more humanized health care delivery system, not to promote passivity. I have no problem with basic patient responsibilities (such as those spelled out in the Michigan law) so long as we do not lose sight of their basic objective: making health care a partnership with the patient having the final say as to what will be done with his or her body. Increased litigation is probably a ted herring, and even if it were not, I would argue that rights are too important to be the victims of economic considerations. Patients have rights because they are citizens, and it is time that we begin to take their rights seriously. This will change the way care is delivered, and the change will not be without costs.

\section{References}

1. See, e.g., Report of the Secretary's Commission on Medical Malpractice, DHEW Publ. No. (OS)73-88 (1973) at 67-81.

\section{Medical Malpractice}

Berg RN, Harper TD, Should Health Care Practitioners Be Allowed to Exculpate Themselves From Liability? - You Be the Judge, JOURNAL OF THE MEDICAL ASSOCIATION OF GEORGIA 70(4): 273-76 (April 1981) [9-059].

Chapman S, Choosing a Lawyer for a Malpractice Case, PHYSICIAN'S MANAGEMENT 21(7): 42-50 (July 1981) [9-167].

Gage SM, Alteration, Falsification, and Fabrication of Records in Medical Malpractice Actions, MEDICAL TRIAL

TECHNIQUE QUARTERLY 27(4): 476-8i5 (Spring 1981) [9-166].

Greenbaum H, Physician Countersuits: A Cause Without Action, PACIFIC LAW JOURNAL 12(3): 745-62 (April 1981).

Greenwald AE, A Positive Approach to Pretrial Discovery, TRIAL 17(6): 48-52 (June 1981) [9-421].

Leonard, Jr. J], Medical Negligence:

Perspective on the Coming Decade, FORUM 16(3): 403-15 (Winter 1981).

Parker JD, Malicious Prosecution Liability of Plaintiffs Counsel for an Unwarranted Medical Malpractice Suit: New Developments in Physician Countersuits for Unfounded Medical Malpractice Claims, Raine v. Drasin, NORTHERN KENTUCKY LAW REVIEW 7(2): 265-86 (1980) [9-624].

Perlman P, Seeing Is Believing: Making Proof More Meaningful, TRIAL 17(6): $34-38,71$ (June 1981) [9-418].

Shrager DS, The Strategy of Theory Development, TRIAL 17(6): 39-42, 71 (June 1981) [9-419].

Stevens GE, Illegible Handwriting and Professional Negligence, MEDICAL TRIAL TECHNIQUE QUARTERLY 27(4): 424-31 (Spring 1981) [9-164].

Tobin MP, Respondents in Discovery: $A$ Pre-Suit Answer to the Medical Malpractice Crisis? LOYOLA UNIVERSITY LAW JOURNAL 11(4): 833-61 (Summer 1980) [9-062].
Trager L, A Defense Viewpoint on Jury Selection in Medical Malpractice Cases, MEDICAL TRIAL TECHNIQUE QUARTERLY 27(4): 399-411 (Spring 1981) [9-162].

Wininger DD, Sams WF, Medical Malpractice: The Alabama Locality Rule, CUMBERLAND LAW REVIEW 11(2): $275-94$ (1980-1981).

Medical Malpractice Arbitration: Dead or Alive? PENNSYLVANIA BAR AsSO. CIATION QUARTERLY 52(2): 111-14 (April 1981).

\section{a) Damages}

Nace BJ, A Checklist for Maximizing Damages, TRIAL 17(6): $43-47$ (June 1981) $[9-420]$.

\section{Medical Malpractice Insurance}

Brown BM, Getting Ready for the Next Malpractice Insturance Crisis, TRUSTEE 34(5): 22-23, 26, 31 (May 1981) [9-150].

Olson MD, The Case for Self-Insurance, TRUSTEE 34(5): 33.37 (May 1981) $[9-151]$.

Self-Insuring Against Medical Malpractice Damages, TOPICS IN HEALTH CARE FINANCING $7(2): 37-47$ (Winter 1980).

\section{Medical Records}

Horty JF, Patient Has Right to Unedited Copy of Her Medical Record, Court Rules, MODERN HealTHCARE 11(6): 136-37 (June 1981) [9-149].

\section{Medicine for Attorneys}

Marek Z, Isolated Subarachnoid Hemorrhage as a Medicolegal Problem, AMERICAN JOURNAL OF FORENSIC MEDICINE AND PATHOLOGY 2(1): 19-22 (March 1981) $[9-443]$.

\section{Mental Health \& the Law}

Appelbaum PS, Civil Litigation and Mental Health: Section 1983, HOSPITAL \& COMMUNITY PSYCHIATRY 32(5): 305-06 (May 1981) [9-414]. 